\title{
DINAMIKA POPULASI KERANG POKEA Batissa violacea var. celebensis VON MARTENS 1897 DI MUARA SUNGAI LASOLO SULAWESI TENGGARA
}

\section{POPULATION DYNAMICS OF POKEA CLAM Batissa violacea var. celebensis VON MARTENS 1897 AT LASOLO ESTUARY OF SOUTHEAST SULAWESI}

\author{
Bahtiar*, La Anadi, Wa Nurgayah, dan Emiyarti \\ Fakultas Perikanan dan Ilmu Kelautan Universitas Halu Oleo, Kendari \\ *E-mail: tiar_77unhalu@yahoo.com
}

\begin{abstract}
Pokea is one of the economically value clam exploited by the fisherman in Southeast Sulawesi. The aim of this study was to determine population dynamics of the pokea at Lasolo estuary in Southeast Sulawesi. Samples of the pokea were collected each month for one year from January to December 2014 using purposive random sampling based on swept area method using a traditional gear, which fisherman called "tangge" at the Lasolo estuary. The density of the clam based on the size and time was determined using Mann Whitney $U$ test whereas density towards production and biomass was analyzed by linear regression. The results showed that the size of the pokea ranged from 0,15-8,09 cm and the density of the pokea ranged from $173-569 \mathrm{ind} / \mathrm{m}^{2}$. There was a significantly different in the density of the pokea based on the size. The highest density was dominated by the pokea 1,74-2,26 cm and 2,80-3,32 cm. However, no significantly different was observed in the density of the pokea based on the time. Pokea size 5,45-5,97 cm $\left(3,02 \mathrm{gMK} / \mathrm{m}^{2} / \mathrm{yr}\right)$ had the highest individuall, somatic production while pokea size 2,80-3,32 cm $\left(160,87 \mathrm{gMK} / \mathrm{m}^{2} / \mathrm{yr}\right)$ had the highest annual population production. Biomass population ranged 0,0002-20,07 $\mathrm{gMK} / \mathrm{m}^{2}$ with the highest biomass occured at the size 2,80$3,32 \mathrm{~cm}\left(20,069 \mathrm{gMK} / \mathrm{m}^{2}\right)$. The turnover rate (P/B) of pokea was 8,01/year.
\end{abstract}

Keywords: pokea, density, production, biomass, turnover, estuary

\begin{abstract}
ABSTRAK
Pokea merupakan jenis kerang bernilai ekonomis yang dieksploitasi nelayan Sulawesi Tenggara. Penelitian ini bertujuan untuk mengetahui dinamika populasi kerang pokea di muara Sungai Lasolo Sulawesi Tenggara. Sampel kerang pokea dikumpulkan secara periodik setiap bulan selama setahun (Januari-Desember 2014) di muara Sungai Lasolo Sulawesi Tenggara. Sampel kerang dikumpulkan secara acak berdasarkan luas sapuan alat tangkap tradisional (tangge). Kepadatan kerang berdasarkan ukuran dan waktu pengamatan diuji dengan U-Mann Whitney sedangkan kepadatan terhadap produksi dan biomassa masing-masing dianalisis menggunakan regresi linear sederhana. Hasil penelitian menunjukkan bahwa kerang pokea ditemukan dari ukuran 0,15-1,67 cm sampai 7,57-8,09 cm, dengan kepadatan berkisar 173-569 ind $/ \mathrm{m}^{2}$. Kepadatan tinggi ditemukan dari ukuran 1,74-2,26 cm sampai 2,80-3,32 cm, yang berbeda nyata dengan kelas ukuran lain, sedangkan kepadatan kerang tidak berbeda nyata di setiap waktu pengamatan. Produksi somatik individu tertinggi ditemukan pada ukuran $5,45-5,97 \mathrm{~cm}\left(3,02 \mathrm{gMKBC} / \mathrm{m}^{2} / \mathrm{thn}\right)$ sedangkan produksi populasi tahunan terbesar terdapat pada ukuran 2,80-3,32 $\mathrm{cm}$ sebesar $160,87 \mathrm{~g} \mathrm{MKBC} / \mathrm{m}^{2} / \mathrm{thn}$. Biomassa pokea berkisar $0,0002-20,07$ $\mathrm{gMKBC} / \mathrm{m}^{2}$ dengan biomassa terbesar terdapat pada ukuran 2,80-3,32 sebesar $20,069 \mathrm{gMKBC} / \mathrm{m}^{2}$. Kemampuan pulih $(P / B)$ pokea sebesar 8,01/thn.
\end{abstract}

Kata kunci: pokea, kepadatan, produksi, biomassa, kemampuan pulih, Lasolo

\section{PENDAHULUAN}

Kerang pokea Batissa violacea var. celebensis, von Martens 1897 merupakan salah satu jenis kerang-kerangan yang termasuk dalam Famili Corbicullidae (Jutting, 1953). Secara umum, kerang ini belum diketahui secara luas di Indonesia dan 
dunia internasional/perdagangan dengan nama yang populer sehingga penamaannya merujuk pada nama daerah di Sulawesi Tenggara yang dikenal dengan nama kerang pokea (Bahtiar, 2012).

Secara geografi, kerang pokea tersebar dari Sumatera, Jawa, Papua Barat, Sulawesi (Djajasasmita, 1977), Filipina (Mayor et al., 2016), sampai Pasifik Selatan (Dudgeon dan Morton, 1989; Morton, 1991; Thangavelu et al., 2011). Kerang ini menghuni perairan muara sungai yang terdistribusi dan menempati seluruh relung sungai (tengah dan tepi sungai) (Bahtiar et al., 2012a). Beberapa jenis kerang sungai mempunyai kemampuan yang besar dalam mengambil dan memanfaatkan sumber makanan yang terdapat di perairan melalui 3 bentuk mekanisme makan yaitu: filter feeder (Vaughn et al., 2008), suspension feeder dan pedal feeder (Arapov et al., 2010; Nichols et al., 2005). Kerang mempunyai pertumbuhan dan reproduksi yang tinggi yang ditandai dengan sangat cepat mencapai ukuran dewasa (Bahtiar et al., 2008; Bahtiar et al., 2015; Aldridge, 1999) dan melakukan pemijahan sepanjang tahun dengan 2 kali puncak pemijahan dalam setahun (Beasley et al., 2000; Yanovich, 2015; Etim, 1996; Rua et al., 2003). Kondisi ini menghasilkan biomassa kerang yang besar sehingga laju kemampuan pulih kerang di sungai sangat tinggi dibandingkan kerang pada ekosistem lain (Sousa et al., 2008; Bahtiar, 2012).

Kerang secara umum (termasuk pokea) merupakan sumber protein dan nutrisi yang baik bagi manusia (Yeni, 2012). Daging kerang pokea telah dikonsumsi oleh masyarakat Sulawesi Tenggara sehingga sebagian nelayan mengumpulkan kerang ini secara intensif dan menjadikannya sebagai mata pencaharian utama. Hasil penelitian Bahtiar dan Hamzah (2007) dan Bahtiar (2012) menunjukkan bahwa kerang pokea yang tereksploitasi di Sungai Pohara telah mengalami lebih tangkap ditandai dengan kepadatan kerang yang semakin rendah (Bahtiar et al., 2012b) dan ukuran kerang yang semakin kecil (Bahtiar, 2012). Kondisi ini dapat mempengaruhi dinamika populasi (produksi, biomassa dan kemampuan pulih) kerang pokea di muara Sungai Lasolo.

Penelitian pada dinamika populasi (produksi, biomassa dan kemampuan pulih) kerang di Indonesia masih sangat jarang dilakukan walaupun penelitian serupa di negara lain telah berkembang pesat. Beberapa penelitian produksi, biomassa kerang air tawar yang tercatat yaitu: Eurhomalea exalbida (Lomovasky et al., 2002), Corbicula fluminea (Sousa et al., 2008), Keletistes rhizoecus (Zabbey et al., 2010), Batissa violacea var. celebensis (Bahtiar, 2012), Anodonta sp. (Aldridge, 1999). Namun penelitian terhadap kerang pokea khususnya dinamika populasi (produksi, biomassa, dan kemampuan pulih) belum sama sekali dilakukan sehingga penelitian ini mempunyai arti penting dalam menyediakan informasi awal bagi pengelolaan sumberdaya kerang ini di masa mendatang.

Penelitian ini bertujuan untuk mengetahui dinamika populasi (produksi, biomassa dan kemampuan pulih) kerang pokea di muara Sungai Lasolo Sulawesi Tenggara. Hasil penelitian ini diharapkan dapat memberikan informasi dalam upaya pengelolaan sumberdaya kerang pokea di Sulawesi Tenggara.

\section{METODE PENELITIAN}

\subsection{Waktu dan Tempat Penelitian}

Sampel kerang pokea dikumpulkan secara periodik setiap bulan selama 1 tahun dari bulan Januari-Desember 2014 di muara Sungai Lasolo Kabupaten Konawe Utara dengan titik ordinat dari $\mathrm{S}=03^{\circ} 30^{\prime} 20,3^{\prime \prime} \mathrm{E}=$ $122^{\circ} 09^{\prime} 05,9^{\prime \prime}$ sampai $\mathrm{S}=03^{\circ} 31^{\prime} 55,1^{\prime \prime} \quad \mathrm{E}=$ $\left.122^{\circ} 13^{\prime} 14,6^{\prime \prime}\right)$ (Gambar 1). 


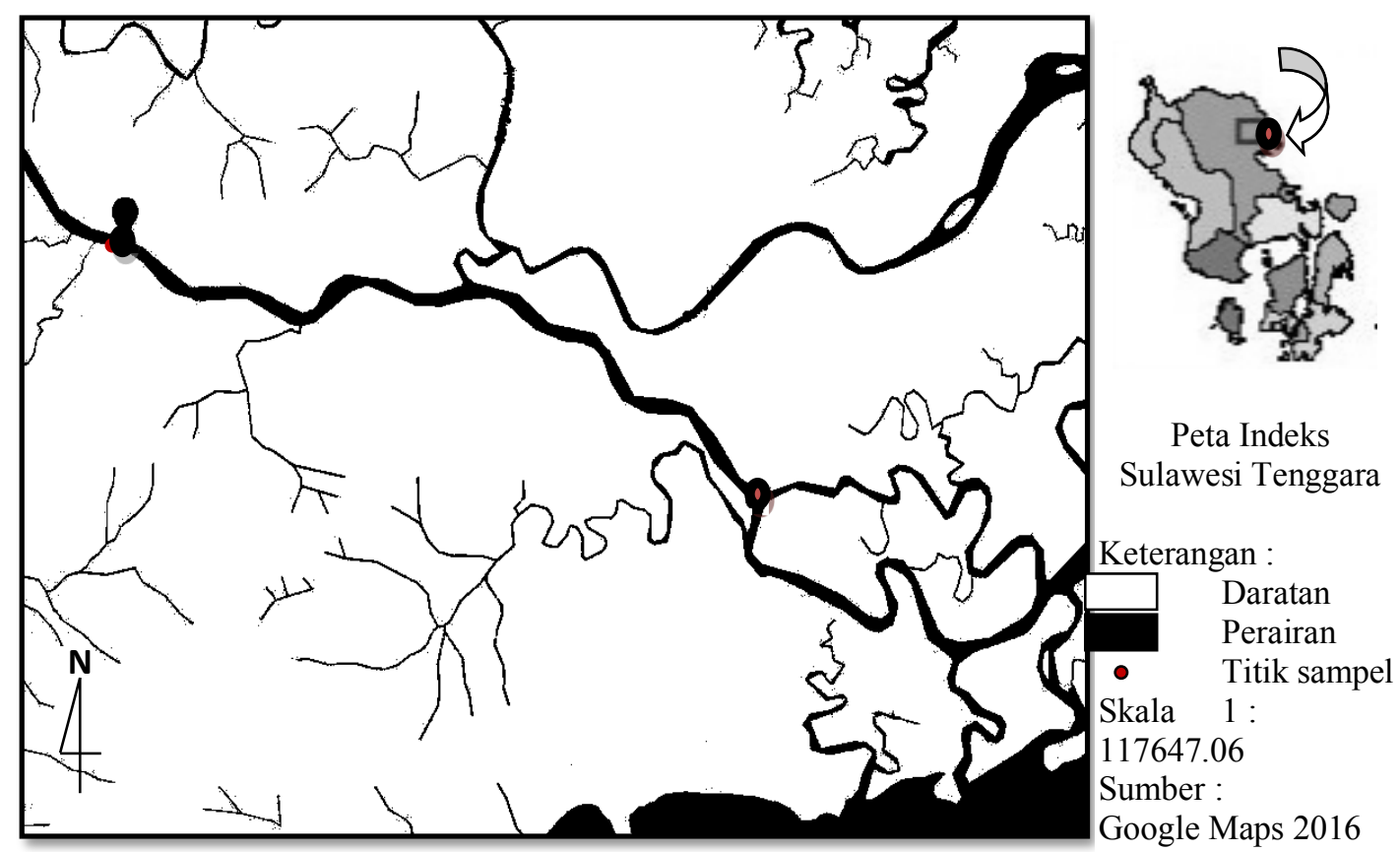

Gambar 1. Peta lokasi penelitian di muara Sungai Lasolo Sulawesi Tenggara (Bahtiar, 2016).

\subsection{Bahan dan Data}

Bahan yang digunakan dalam penelitian ini yaitu: sampel kerang pokea. Data yang dikumpulkan dalam penelitian ini meliputi: data kepadatan kerang pokea, lebar cangkang, berat total kerang, berat daging tanpa cangkang, dan berat kering, serta kualitas perairan: total padatan terlarut (TDS), bahan organik total (TOM), bahan organik sedimen (BOS), dan klorofil-a.

\subsection{Teknik Pengumpulan Data}

\subsubsection{Pengumpulan Data dan}

\section{Pengamatan Sampel Kerang Pokea}

Sampel kerang dikumpulkan secara acak (random sampling) pada lima titik pengambilan di seluruh bagian perairan menggunakan alat tangkap tradisional yang masyarakat setempat menyebutnya dengan nama tangge (Bahtiar, 2016) (Gambar 2).

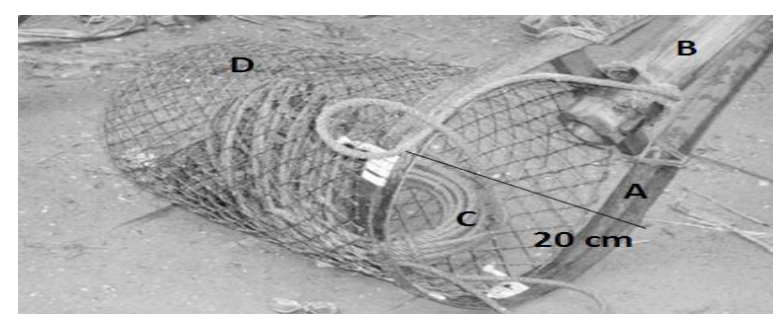

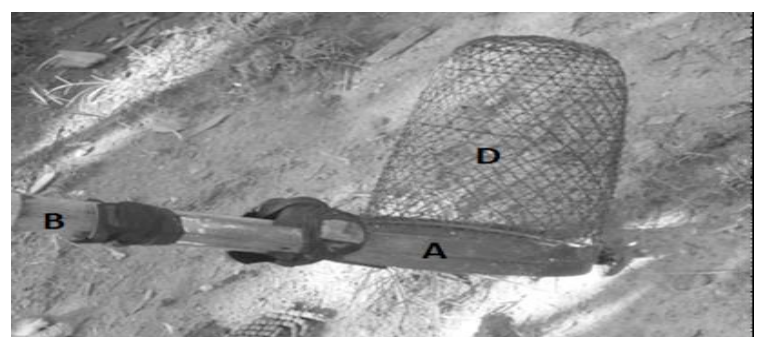

Gambar 2. Alat tangkap tangge yang digunakan dalam pengambilan sampel kerang pokea.

Keterangan: $(\mathrm{A}=$ besi pelingkar, $\mathrm{B}=$ bambu, $\mathrm{C}=$ tali dan $\mathrm{D}=$ mata tangge) dalam berbagai ukuran.

Jumlah tarikan alat dalam setiap pengambilan sebanyak 10 kali tarikan. Selanjutnya sampel kerang pokea dihitung jumlahnya dan dikonversi ke dalam satuan luas (ind $/ \mathrm{m}^{2}$ ). Sampel kerang diukur lebar cangkangnya (LC) kemudian ditimbang berat total dengan cangkang/massa total (MT) dan massa basah bebas cangkang (MBBC). Selanjutnya dikeringkan meng-gunakan oven selama 48 jam pada suhu $70^{\circ} \mathrm{C}$ sehingga diperoleh massa kering bebas cangkang 
(MKBC) atau SFDW (Shell Free Dry Mass) (Abrahao et al., 2010).

\subsubsection{Pengumpulan Data Kualitas Per- airan}

Sampel kualitas air yang diamati meliputi: total padatan terlarut (TDS), bahan organik air (TOM), bahan organik sedimen (BOS) dan klorofil a. Sampel kualitas air dikumpulkan bersamaan dengan pengambilan sampel kerang pokea. Sampel TDS diukur menggunakan alat TDS-3, sedangkan sampel kualitas air seperti: bahan organik air, bahan organik sedimen,dan klorofil-a diukur menggunakan spektrofotometer di Laboratorium Analitik Universitas Halu Oleo.

\subsection{Analisa Data}

\subsubsection{Kepadatan}

Kepadatan kerang pokea dihitung sebagai fungsi dari luas daerah yang diliput dalam pengambilan sampel (ind $/ \mathrm{m}^{2}$ ), sedangkan kepadatan rata-rata di setiap waktu dan selang kelas ukuran kerang pokea dianalisis dengan uji U Mann-Whitney (Ocana, 2015):

$K=n / A$

Keterangan: $\mathrm{K}=$ kepadatan $\left(\mathrm{ind} / \mathrm{m}^{2}\right), \mathrm{n}=$ jumlah individu (ind.), dan $\mathrm{A}=$ luas area $\left(\mathrm{m}^{2}\right)$.

\subsubsection{Produksi}

Total produksi tahunan (annual production) dihitung dengan menggunakan metode laju pertumbuhan massa spesifik (mass specific growth rate method) (Laudien et al., 2003; Hermann et al., 2009, Çolakoğlu, 2014) yaitu:

$P=\sum_{1}^{1} N i . M i . G i\left(\mathrm{~g} \mathrm{MKBC} / \mathrm{m}^{2} / \mathrm{thn}^{1}\right)$

Keterangan: $\mathrm{P}=$ produksi tahunan, $\mathrm{Ni}=$ kepadatan rata-rata (ind $/ \mathrm{m}^{2}$ ) pada kelas lebar $\mathrm{ke}-\mathrm{i}, \mathrm{Mi}=\mathrm{MKBC}$ individu rata-rata pada kelas lebar ke-i, dan Gi = laju pertumbuhan massa spesifik pada kelas lebar ke-i.

Laju pertumbuhan massa spesifik (mass specific growth rate method) (Gi) dihitung menggunakan persamaan (Laudien et al., 2003; Hermann et al., 2009; Çolakoğlu, 2014) yaitu:

$G i=b . K \cdot\left[\left(\frac{L \infty}{L i}\right)-1\right] / t h n^{1}$

Nilai koefisien $b$ didapatkan dari hubungan lebar cangkang (L) dan berat kering (MKBC) yang ditentukan dengan menggunakan analisis regresi sederhana yaitu:

$M K B C=a \cdot L^{b}$

Keterangan: $a$ dan $b=$ koefisien, $L=$ lebar cangkang, $\mathrm{MKBC}=$ massa kering bebas cangkang $(\mathrm{g}), \mathrm{K}=$ koefisien pertumbuhan von Bertalanffy, $\mathrm{L}_{\infty}=$ panjang maksimun kerang pokea, dan $\mathrm{Li}=$ lebar cangkang pada kelas lebar ke-i.

\subsubsection{Biomassa}

Rata-rata biomassa tahunan (annual biomass) $\left(\bar{B}\left(\mathrm{gMKBC} / \mathrm{m}^{2}\right)\right.$ dihitung dengan persamaan (Laudien et al., 2003; Hermann et al., 2009, Çolakoğlu, 2014) yaitu:

$B=\sum N i . M i$

Keterangan: $\mathrm{Ni}=$ kepadatan rata-rata (ind $/ \mathrm{m}^{2}$ ) pada kelas lebar ke-i, Mi $=$ MKBC individu rata-rata pada kelas lebar ke-i

\subsubsection{Kemampuan Pulih}

Kemampuan pulih (turnover rate) (T) dihitung dari total produksi tahunan $(\mathrm{P})$ dibagi biomassa tahunan rata-rata (B) yaitu:

$T=P / B$

\subsubsection{Kualitas Perairan}

Kualitas lingkungan perairan dianalisis secara deskriptif dengan mengamati kecenderungan dinamika kualitas perairan 
secara temporal yang masing-masing ditampilkan dalam bentuk grafik.

\section{HASIL DAN PEMBAHASAN}

\subsection{Hasil}

\subsubsection{Kepadatan}

Hasil pengamatan menunjukkan bahwa kepadatan kerang Batissa violacea var. celebensis bervariasi selama periode penelitian. Kepadatan terendah terdapat di bulan Oktober sebesar $173 \mathrm{ind} / \mathrm{m}^{2}$ dan tertinggi terjadi di bulan Juni sebesar 569,6 ind $/ \mathrm{m}^{2}$ (Gambar 3).

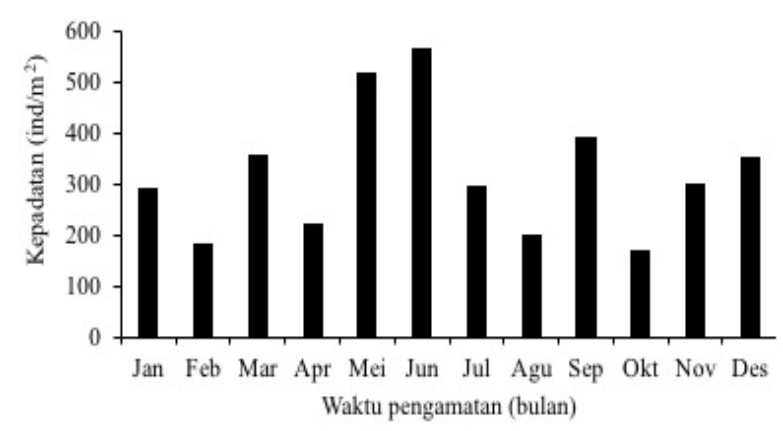

Gambar 3. Kepadatan kerang Batissa violacea var. celebensis berdasarkan waktu pengamatan di muara Sungai Lasolo.

Hasil uji U-Mann Whitney $(\alpha=0,05)$ menunjukkan bahwa kepadatan kerang tidak nyata berbeda di setiap waktu pengamatan.

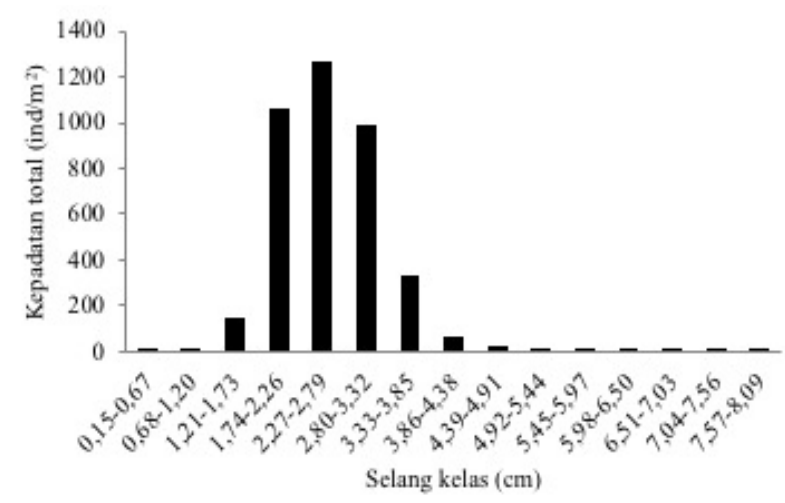

Gambar 4. Kepadatan kerang Batissa violacea var. celebensis berdasarkan interval kelas di muara Sungai Lasolo.
Kepadatan kerang pokea tertinggi ditemukan dari ukuran 1,74-2,26 cm sampai 2,80-3,32 cm. Hasil uji U-Mann Whitney $(\alpha=0,05)$ menunjukkan bahwa kepadatan pokea pada ukuran tersebut nyata berbeda dengan ukuran lainnya. Ukuran terkecil $(1,74-2,26 \mathrm{~cm}$ sampai $1,21-1,73 \mathrm{~cm})$ dan terbesar (3,33-3,85 $\mathrm{cm}$ sampai 7,57-8,09 cm) mempunyai kepadatan rendah (Gambar 4).

\subsubsection{Produksi}

Hasil analisis produksi somatik individu $B$. violacea var. celebensis tertinggi ditemukan pada lebar cangkang 5,45-5,97 cm $\left(3,02 \mathrm{gMKBC} / \mathrm{m}^{2} / \mathrm{thn}\right)$. Adapun produksi somatik individu terendah terdapat pada lebar cangkang 0,15-0,67 $\mathrm{cm}$ sebesar 0,16 $\mathrm{gMKBC} / \mathrm{m}^{2} /$ tahun. Analisis pada produksi populasi tahunan (annual production) dihitung menggunakan data kepadatan $(\mathrm{Ni})$ dan laju pertumbuhan massa spesifik (Gi) serta rata-rata berat kering pada masingmasing kelas ukuran (Mi) B. violacea var. celebensis. Produksi populasi tahunan $B$. violacea var. celebensis berkisar 0,012-160,9 $\mathrm{gMKBC} / \mathrm{m}^{2} /$ thn atau rata-rata sebesar 60,48 $\mathrm{gMKBC} / \mathrm{m}^{2} /$ thn dengan total produksi $549,99 \mathrm{gMKBC} / \mathrm{m}^{2} / \mathrm{thn}$. Nilai produksi populasi tahunan terbesar terdapat pada ukuran 2,80-3,32 sebesar 160,87 $\mathrm{gMKBC} / \mathrm{m}^{2} / \mathrm{thn}$, sedangkan nilai produksi populasi tahunan terkecil sebesar 0,012 $\mathrm{gMKBC} / \mathrm{m}^{2} /$ thn pada kelas ukuran $0,15-0,67$ cm (Gambar 5).

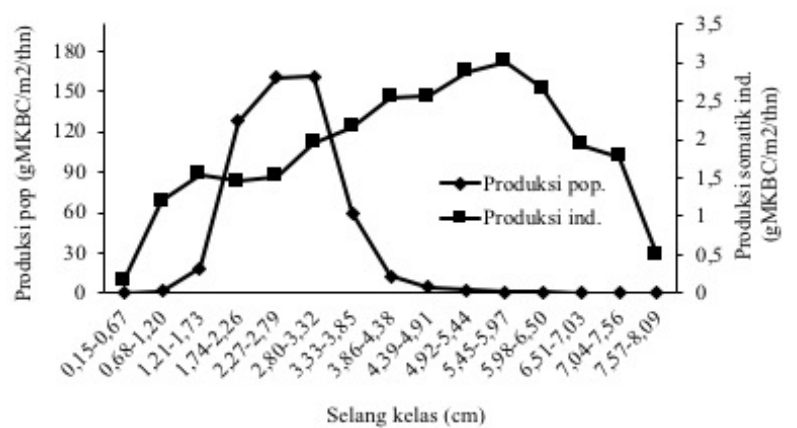

Gambar 5. Produksi somatik individu dan produksi populasi tahunan kerang $B$. violacea var. celebensis di muara Sungai Lasolo. 


\subsubsection{Biomassa Populasi dan Ke- mampuan Pulih}

Hasil analisis biomassa populasi $B$. violacea var. celebensis di muara Sungai Lasolo pada setiap kelas ukuran menunjukkan nilai yang bervariasi berkisar 0,0002 $20,07 \mathrm{gMKBC} / \mathrm{m}^{2}$. Nilai biomassa terkecil sebesar $0,000192 \mathrm{gMKBC} / \mathrm{m}^{2}$ ditemukan pada kelas ukuran 0,15-0,67 cm. Nilai biomassa terbesar terdapat pada kelas ukuran 2,80-3,32 yang ditemukan sebesar 20,069 $\mathrm{gMKBC} / \mathrm{m}^{2}$ (Gambar 6). Rasio produksi terhadap biomassa $(P / B)$ sebesar $8,01 /$ thn.

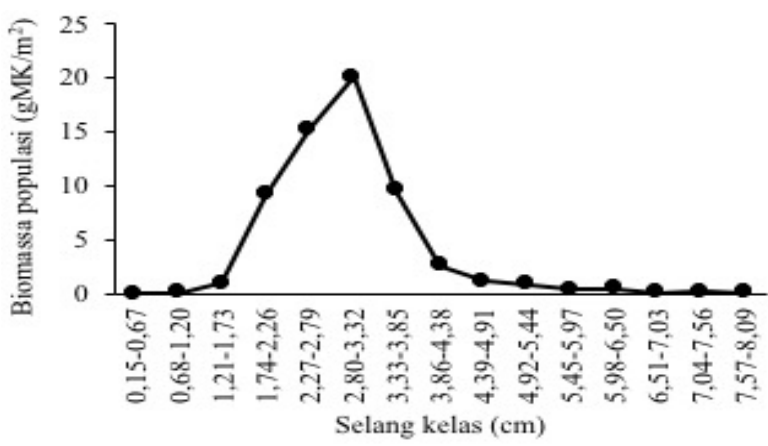

Gambar 6. Biomassa B. violacea var. celebensis pada ukuran berbeda di muara Sungai Lasolo.

\subsubsection{Hubungan Kepadatan dan \\ Produksi-Biomassa Kerang Pokea}

Hasil analisis regresi linear hubungan kepadatan dan produksi tahunan populasi $(\alpha=0,05 ; P$ value $=0,00)$ dan biomassa kerang pokea $(\alpha=0,05 ; \quad P \quad$ value $=0,00)$, dengan koefisien determinasi $\left(\mathrm{R}^{2}\right)$ sebesar $97,36 \%$

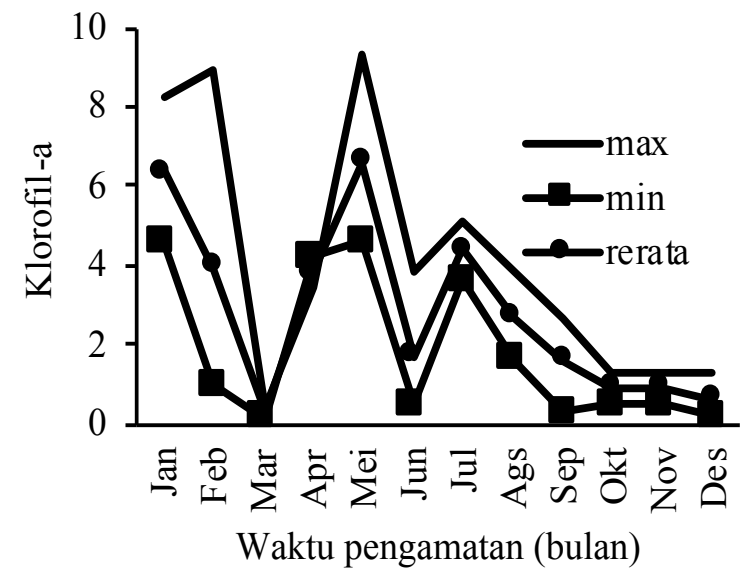

menunjukkan adanya hubungan erat kepadatan terhadap produksi tahunan populasi. Demikian halnya dengan hasil analisis regresi linear kepadatan dan biomassa kerang pokea $(\alpha=0,05 ; \quad P$ value $=0,00)$, dengan koefisien determinasi $\left(\mathrm{R}^{2}\right)$ sebesar $82,42 \%$ menunjukkan bahwa adanya hubungan produksi tahunan populasi kerang dan peningkatan biomassa populasi kerang (Gambar 7).

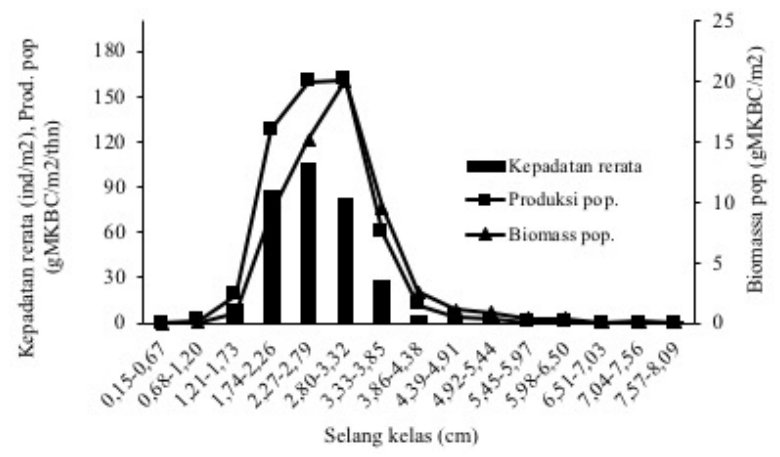

Gambar 7. Kepadatan rata-rata, estimasi produksi dan biomassa tahunan pada setiap kelas ukuran berbeda B. violacea var. celebensis di muara Sungai Lasolo.

\subsubsection{Kualitas Lingkungan Perairan}

Hasil analisis kualitas lingkungan perairan yang terukur selama penelitian menunjukkan bahwa klorofil-a berkisar 0,29,3 mg/L, TOM berkisar 1,04-11,4 mg/L, bahan organik substrat berkisar 0,1-5,6 \% dan TDS berkisar 143-523 mg/L (Gambar 8).

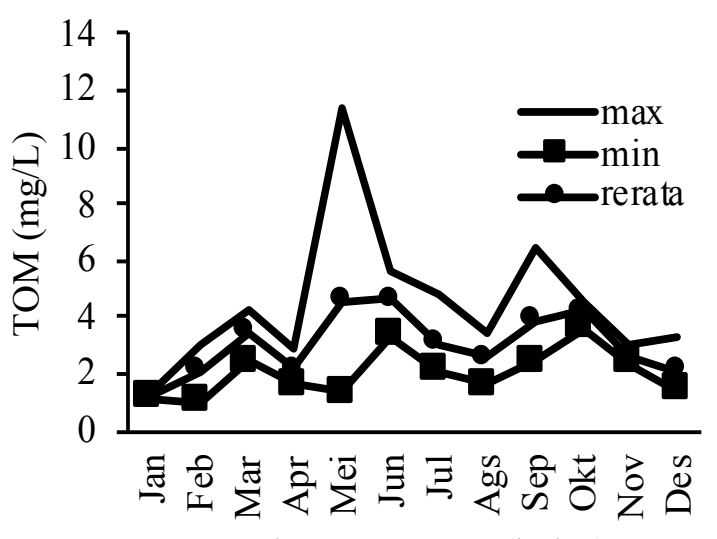

Waktu pengamtan (bulan) 

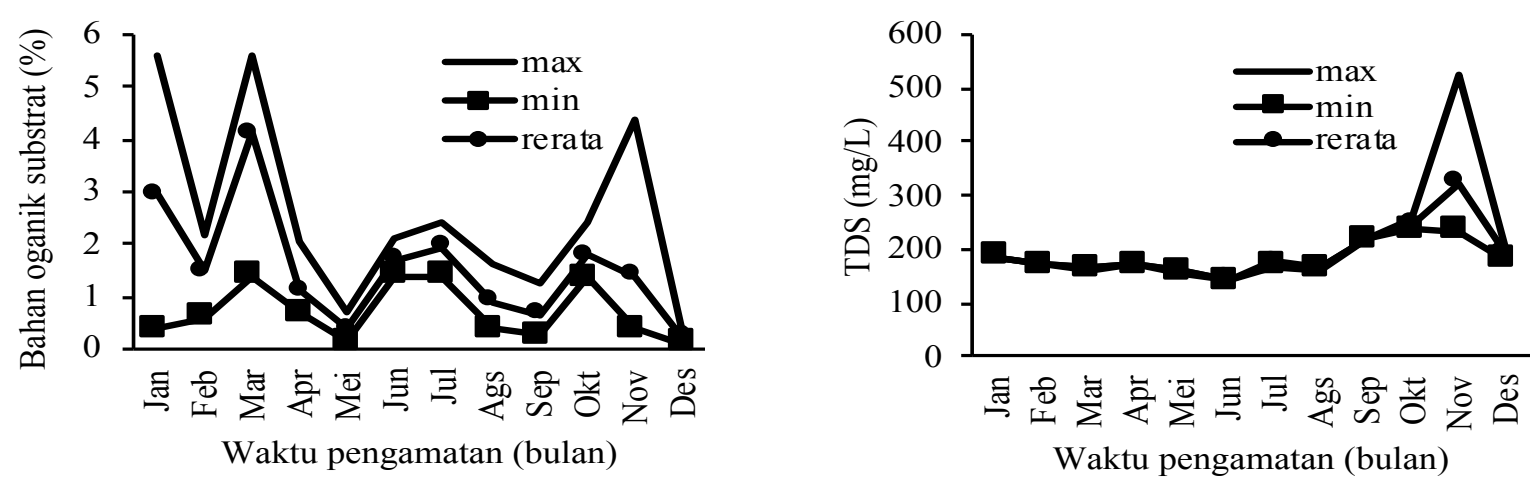

Gambar 8. Kualitas perairan selama penelitian di muara Sungai Lasolo.

\subsection{Pembahasan}

Kepadatan kerang pokea di muara Sungai Lasolo relatif berfluktuatif di setiap waktu pengamatan, Namun demikian perubahan kepadatan secara temporal cenderung tidak signifikan atau tidak berbeda nyata. Kondisi ini menunjukkan bahwa penyebaran populasi kerang relatif merata sebagai keberhasilan dari rekrutmen (penambahan baru) ke daerah penangkapan di setiap saat. Kerang pokea merupakan jenis kerang yang melakukan pemijahan di sepanjang waktu (partial spawner) walaupun ditemukan mempunyai 2 musim puncak pemijahan (Bahtiar, 2012), sehingga penangkapan kerang yang tinggi di muara Sungai Lasolo tidak signifikan mempengaruhi kepadatan kerang pokea. Namun pengaruh penangkapan dapat diketahui dari ukuran kerang yang tertangkap didominasi oleh kerang berukuran kecil yang masih jauh dari ukuran panjang maksimun dan telah berada pada tingkat pemanfaatan yang lebih tangkap (Bahtiar et al., 2016).

Berdasarkan studi literatur, kepadatan kerang pokea di muara Sungai Lasolo sangat tinggi dibandingkan dengan kerang air tawar yang sama atau kerang lainnya seperti kerang pokea di muara Sungai Pohara (Bahtiar et al.,
2012), Batissa violacea di Sungai Cagayan Filipina (Mayor et al., 2016), dan Anodonta cygnea, A. anatine, Unio pictorum (Ercan et al., 2013). Demikian halnya kepadatan kerang pokea jauh lebih tinggi jika dibandingkan dengan kerang yang menghuni perairan payau dan pantai seperti: Pedalion isognomun (Irma dan Sofyatuddin, 2012), Polymesoda caroliniana (Duobinis, et al., 1982; Clemente dan Ingole, 2011), Mesodesma mactroides (Hermann, et al., 2010) dan Donax striatus (Ocana, 2015). Namun, kepadatan kerang pokea jauh lebih rendah dibandingkan dengan jenis kerang invasif seperti Corbicula fluminea (Paschoal et al., 2013), dan Limnoperna fortunei (Musin et al., 2015) (Tabel 1). Secara umum, perbedaan kepadatan bivalvia (termasuk kerang pokea) di beberapa tempat telah dibahas oleh peneliti. Perbedaan kepadatan tersebut berhubungan dengan letak geografis dan iklim (Lomolino et al., 2006; Compton et al., 2008), tipe dan kondisi habitat (Davis et al., 2001; Flores-Garza et al., 2014), fluktuasi parameter lingkungan termasuk ketersediaan makanan dan nutrien (Kabir et al., 2014; Nasution dan Zulkifli, 2014) serta kepadatan predator dan mangsa (Printrakoon et al., 2008).

Tabel 1. Kepadatan beberapa jenis kerang diberbagai tipe perairan dunia.

\begin{tabular}{llcc}
\hline \multicolumn{1}{c}{ Lokasi } & \multicolumn{1}{c}{ Spesies } & Kepadatan $\left(\mathrm{ind} / \mathrm{m}^{2}\right)$ & Sumber \\
\hline Sungai Cagayan, Filipina & Batissa violacea & $0,12-11,12$ & Mayot et al., 2016 \\
Danau Irupe & Limnoperna & 2765 & Musin et al., 2015 \\
Danau Mini & fortunei & 981 & \\
\hline
\end{tabular}




\begin{tabular}{|c|c|c|c|}
\hline Lokasi & Spesies & Kepadatan (ind $/ \mathrm{m}^{2}$ ) & Sumber \\
\hline $\begin{array}{l}\text { Pantai berpasir Las } \\
\text { Balsas, Cuba }\end{array}$ & Donax striatus & $24-892$ & Ocana, 2015 \\
\hline Danau Sapanca, Turki & $\begin{array}{l}\text { Anodonta cygnea } \\
\text { A. anatine } \\
\text { Unio pictorum }\end{array}$ & $\begin{array}{c}30-73 \\
8-15 \\
15-48\end{array}$ & Ercan et al., 2013 \\
\hline Sungai Furnas, Brazil & $\begin{array}{l}\text { Corbicula } \\
\text { fluminea }\end{array}$ & $160-630$ & $\begin{array}{l}\text { Paschoal et al., } \\
2013\end{array}$ \\
\hline $\begin{array}{l}\text { Muara Sungai Pohara } \\
\text { Sulawesi Tenggara }\end{array}$ & $\begin{array}{l}\text { Batissa violacea } \\
\text { var. celebensis }\end{array}$ & & Bahtiar et al., 2012 \\
\hline Pantai Cermin, Riau & $\begin{array}{l}\text { Anadara } \mathrm{sp} \\
\text { Pharus } \mathrm{sp} \\
\text { Geloina } \mathrm{sp} \\
\text { Perna viridis }\end{array}$ & $\begin{array}{l}2,07 \\
2,75 \\
2,53 \\
2,32\end{array}$ & $\begin{array}{l}\text { Suwondo et al., } \\
2012\end{array}$ \\
\hline $\begin{array}{l}\text { Perairan Mangrove, Aceh } \\
\text { Besar }\end{array}$ & $\begin{array}{l}\text { Pedalion } \\
\text { isognomun }\end{array}$ & 8 & $\begin{array}{l}\text { Irma dan } \\
\text { Sofyatuddin, } 2012\end{array}$ \\
\hline Pulau Chorao, India & Polymesoda erosa & $7-12$ & $\begin{array}{l}\text { Clemente dan } \\
\text { Ingole, } 2011\end{array}$ \\
\hline $\begin{array}{l}\text { Pantai Temperate, } \\
\text { Argentina Utara }\end{array}$ & $\begin{array}{l}\text { Mesodesma } \\
\text { mactroides }\end{array}$ & $29-48$ & $\begin{array}{l}\text { Hermann et al., } \\
2010\end{array}$ \\
\hline Rawa Pasut Missisipi & $\begin{array}{l}\text { Polymesoda } \\
\text { caroliniana }\end{array}$ & $126-136$ & $\begin{array}{l}\text { Duobinis et al., } \\
1982\end{array}$ \\
\hline
\end{tabular}

Produksi tahunan populasi kerang pokea cenderung mengalami peningkatan saat berumur muda dan mencapai titik maksimun pada ukuran cangkang 2,80-3,32 $\mathrm{cm}$. Ukuran ini merupakan kerang dewasa yang ditandai dengan gonad matang (Bahtiar, 2012). Selanjutnya produksi tahunan populasi kerang mengalami penurunan yang tajam pada ukuran panjang $>2,80-3,32 \mathrm{~cm}$ dan produksi populasi menjadi stagnan pada umur tua mendekati ukuran panjang maksimun kerang pokea (Lo). Beberapa hal yang menjadi penyebab penurunan produksi populasi pada saat panjang mendekati L $\infty$ pada kerang berkaitan dengan umur produktif, potensi reproduksi yang menurun, rendahnya tingkat kepadatan, atau tingkat eksploitasi kerang yang mengambil ukuran tertentu (Kevrekidis et al., 2009). Umur yang tua sampai mati secara alami, produksi populasi kerang berada pada kondisi yang mendekati stagnan.

Ukuran lebar cangkang setiap jenis kerang mempunyai produksi tahunan populasi puncak berbeda-beda. Kerang $M$. mactroides terus meningkat hingga mencapai puncak pada ukuran $4,7 \mathrm{~cm}$ dan menurun sampai ukuran panjang maksimun $(\mathrm{L} \infty=8,5$ $\mathrm{cm})$ (Hermann et al., 2010). Spesies yang ukurannya lebih kecil dengan panjang maksimun $(\mathrm{L} \infty=3,61 \mathrm{~cm})$ mencapai produksi pada ukuran $2,4 \mathrm{~cm}$ dan terus menurun hingga mencapai panjang maksimun. Kerang E. exalbida dengan L $\infty=$ $7,4 \mathrm{~cm}$ mencapai puncak produksi individu pada ukuran $5 \mathrm{~cm}$ (Lomovasky et al., 2002). Kerang Donax serra dengan $\mathrm{L}_{\infty}=8,2 \mathrm{~cm}$ mencapai produksi maksimal pada ukuran $5,65 \mathrm{~cm}$.

Kelas ukuran lebar cangkang 2,80$3,32 \mathrm{~cm}$ berkontribusi terhadap tingginya nilai kepadatan dan produksi populasi dari kerang pokea dengan nilai masing masing $82,42 \mathrm{ind} / \mathrm{m}^{2}$ dan $160,87 \mathrm{gMK} / \mathrm{m}^{2} / \mathrm{thn}$, selanjutnya mengalami penurunan hingga mencapai lebar cangkang maksimun. Hal ini menunjukkan bahwa kepadatan pada masingmasing kelas ukuran turut menentukan tingkat produksi populasi tahunan kerang pokea. Hal ini dapat diketahui dari hubungan 
produksi dan kepadatan kerang pokea yang menunjukkan bahwa semakin tinggi nilai kepadatan maka produksi kerang juga meningkat dan sebaliknya, semakin rendah nilai kepadatan maka produksinya juga menurun. Ocana (2015) menyatakan bahwa kelas ukuran dengan kepadatan tinggi memiliki kontribusi yang lebih besar terhadap total produksi spesies bivalvia. Hal ini dibuktikan dari kepadatan tertinggi pada kelas ukuran $13 \mathrm{~mm}$ yang berkontribusi terhadap produksi tertinggi populasi kerang sebesar 6,11 $\mathrm{MKBA} / \mathrm{m}^{2} /$ thn (Massa Kering Bebas Abu) dan T. mactroides dengan kepadatan tertinggi pada kelas ukuran 26-30 mm berkontribusi sebesar $46 \%$ dari total produksi kerang tahunan (Turra et al., 2014).

Nilai estimasi produksi tahunan (annual production) pokea di muara Sungai Lasolo adalah $549,99 \mathrm{gMK} / \mathrm{m}^{2} / \mathrm{thn}$ atau setara dengan 94,76 $\mathrm{MKBA} / \mathrm{m}^{2} / \mathrm{thn}$ (Ricciardi dan Bourget, 1998). Nilai ini lebih tinggi dari beberapa spesies bivalvia yang hidup di perairan tawar dan perairan pantai intertidal dan lepas pantai (Tabel 2). Perbandingan nilai total produksi tahunan menunjukkan bahwa perairan muara sungai merupakan habitat kerang pokea dengan ketersediaan makanan yang lebih baik dibandingkan perairan lainnya karena salah satu faktor tingginya total produksi tahunan populasi kerang adalah ketersediaan makanan yang tinggi dan kemampuan intensitas pemanfaatan sumber makanan (Turra et al., 2014).

Pembentukan massa jaringan hidup per luas $1 \mathrm{~m}^{2}$ kerang pokea sangat tinggi yang puncaknya terjadi pada ukuran lebar cangkang 2,80-3,32 cm. Ukuran lebar cangkang kerang pokea pada biomassa puncak ditemukan berbeda dengan kepadatan puncak. Kepadatan tertinggi terdapat pada ukuran 2,27-2,79 cm $\left(105,51\right.$ ind. $\left./ \mathrm{m}^{2}\right)$, sedangkan biomassa tertinggi terdapat pada ukuran yang lebih besar yakni 2,80-3,36 cm. Hal ini menarik karena tingginya kepadatan kerang $B$. violacea var. celebensis pada ukuran tersebut tidak selalu diikuti dengan biomassanya yang tinggi atau dengan kata lain biomassa tertinggi bisa saja berada pada kepadatan yang lebih rendah. Perbedaan tersebut dapat disebabkan oleh penurunan populasi kerang pokea karena tekanan penangkapan yang mengambil ukuran di atas 2,80-3,36 (Bahtiar et al., 2016) yang mempunyai biomassa lebih besar sehingga memberikan pengaruh pada pembentukan biomassa pada ukuran tersebut.

Secara umum, biomassa tahunan (annual production) kerang pokea lebih tinggi dibanding dengan spesies bivalvia lainnya (Tabel 2) walaupun berbeda jauh dengan biomassa Corbicula fluminea (Sousa et al., 2008), Donax trunculus (Kevrekidis et al., 2009) dan E. exalbida (Lomovasky et al., 2002). Perbedaan biomassa pada setiap jenis kerang tersebut dipengaruhi oleh berbagai hal diantaranya adalah: 1) kompetisi ruang (Guissan et al., 2006), 2) pasokan makanan (Darr et al., 2014; Hermann et al., 2010), dan 3) sejarah hidup kerang. Daerah pantai yang mengalami up welling ditemukan mempunyai biomassa tahunan lebih besar dibanding daerah non up welling (Laudien et al., 2003). Selanjutnya kerang yang mempunyai umur pendek, oportunis dan invasif cenderung mempunyai biomassa lebih besar seperti pada kerang Corbicula fluminea (Sousa et al., 2008).

Pola peningkatan dan penurunan biomassa untuk masing-masing kelas ukuran kerang $B$. violacea var. celebensis di muara Sungai Lasolo, secara umum mengikuti dinamika laju produksinya. Kerang yang ukuran cangkangnya lebih kecil (umur muda) mengalami peningkatan nilai produksi yang sangat cepat dan mencapai puncaknya pada ukuran 2,80-3,32 $\mathrm{cm}$ dan setelah itu terus mengalami penurunan. Pola yang sama pada ukuran tersebut juga ditunjukkan pada biomassa kerang pokea. Meskipun demikian, produksi pada ukuran cangkang 3,33-3,85 cm sangat rendah namun biomassanya menunjukkan nilai yang hampir sama dengan nilai biomassa pada ukuran cangkang $2,0 \mathrm{~cm}$. Disisi lain, diketahui bahwa pada ukuran ini 
produksinya cukup tinggi yang dapat mencapai $128,05 \mathrm{gMK} / \mathrm{m}^{2} /$ thn dibandingkan produksi kerang pada ukuran 3,33-3,85 cm yang hanya sekitar $59,8 \mathrm{gMK} / \mathrm{m}^{2} / \mathrm{thn}$. Hal ini menunjukkan bahwa perubahan ukuran atau umur kerang ke arah yang lebih tua dapat saja menurunkan secara drastis nilai produksinya namun tidak begitu signifikan dengan penurunan biomassanya.

Kemampuan pulih populasi kerang pokea di muara Sungai Lasolo lebih tinggi dibanding kerang lain seperti spesies: Trochulus plebeius sebesar 1,37/thn (Abrahao et al., 2010), Donax serra (Zabbey et al., 2010), Donax striatus $(3,47 / \mathrm{thn})$ (Ocana, 2015), Polymesoda solida (0,23/thn) (Rueda dan Urban, 1998) (Tabel 2). Perbedaan kemampuan pulih terkait dengan kecepatan pertumbuhan setiap spesies.
Pertumbuhan yang cepat dan rentang hidup (longevity) yang pendek menunjukkan kemampuan pulih yang cepat, kemampuan pulih menjadi rendah bila ukuran individu besar, tingkat pertumbuhan rendah serta rentang hidup panjang (Cardoso dan Veloso, 2003). Kerang pokea mempunyai nilai koefisien pertumbuhan sangat tinggi dibanding spesies lain yakni sebesar 1,8/thn dalam mencapai pertumbuhan maksimun $(\mathrm{L} \infty)=8,07$ (Bahtiar et al., 2016).

Pola laju kemampuan pulih juga berubah seiring pergeseran lintang yaitu semakin ke arah tropis maka rasio $\mathrm{P} / \mathrm{B}$ semakin tinggi (Abrahao et al., 2010). Namun hal ini hanya berlaku untuk spesies yang sama, sedangkan spesies berbeda lebih dipengaruhi oleh ketersediaan makanan (Cardoso dan Veloso, 2003).

Tabel 2. Perbandingan produksi sekunder $\left(\mathrm{P}, \mathrm{g} \mathrm{MK} / \mathrm{m}^{2} / \mathrm{thn}\right)$ dan kemampuan pulih (rasio $\mathrm{P} / \mathrm{B} / \mathrm{thn}$ ) beberapa spesies bivalvia di lokasi berbeda.

\begin{tabular}{|c|c|c|c|c|c|c|c|}
\hline No. & Lokasi & Spesies & $\mathrm{P}$ & $\mathrm{B}$ & $\mathrm{P} / \mathrm{B}$ & Referensi & Keterangan \\
\hline 1. & $\begin{array}{l}\text { Sungai Bodo, } \\
\text { Nigeria }\end{array}$ & $\begin{array}{l}\text { Keletistes } \\
\text { rhizoecus }\end{array}$ & 11,21 & 3,92 & 2,86 & $\begin{array}{l}\text { Zabbey et al., } \\
2010\end{array}$ & $\mathrm{MKBA}^{1}$ \\
\hline 2. & $\begin{array}{l}\text { Salamanca, } \\
\text { Colombian } \\
\text { Caribbean }\end{array}$ & Polymesoda solida & 0,647 & 2,81 & 0,230 & $\begin{array}{l}\text { Rueda dan } \\
\text { Urban, } 1998\end{array}$ & MKBA \\
\hline 3. & $\begin{array}{l}\text { Muara } \\
\text { Sungai } \\
\text { Minho }\end{array}$ & Corbicula fluminea & 463,78 & 160,48 & 2,89 & $\begin{array}{l}\text { Sousa et al., } \\
2008\end{array}$ & MKBA \\
\hline 4. & $\begin{array}{l}\text { Pantai } \\
\text { Marmara }\end{array}$ & Donax trunculus & 96,66 & 92,94 & 1,04 & $\begin{array}{l}\text { Kevrekidis } \\
\text { et al., } 2009\end{array}$ & $\mathrm{MBBC}^{2}$ \\
\hline 5. & $\begin{array}{l}\text { Pantai Brazil } \\
\text { Tenggara }\end{array}$ & Tivela mactroides & 3,23 & 2,67 & 1,21 & $\begin{array}{l}\text { Turra et al., } \\
2014\end{array}$ & MKBA \\
\hline 6. & $\begin{array}{l}\text { Pantai } \\
\text { temperate } \\
\text { Argentina }\end{array}$ & $\begin{array}{l}\text { Mesodesma } \\
\text { mactroides }\end{array}$ & 0,12 & 0,07 & 1,84 & $\begin{array}{l}\text { Hermann et } \\
\text { al., } 2010\end{array}$ & MKBA \\
\hline 7. & $\begin{array}{l}\text { Pantai Las } \\
\text { Balsas, Kuba }\end{array}$ & Donax striatus & 6,11 & 1,76 & 3,47 & Ocana, 2015 & MKBA \\
\hline 8. & $\begin{array}{l}\text { Perairan } \\
\text { Beagle } \\
\text { Channel, } \\
\text { Amerika } \\
\text { Selatan }\end{array}$ & $\begin{array}{l}\text { Eurhomalea } \\
\text { exalbida }\end{array}$ & 22,2 & 185 & 0,12 & $\begin{array}{l}\text { Lomovasky } \\
\text { et al., } 2002\end{array}$ & MKBA \\
\hline 9. & Penelitian ini & $\begin{array}{l}\text { Batissa violacea } \\
\text { var. celebensis }\end{array}$ & 160,9 & 8,02 & 20,07 & $\begin{array}{l}\text { Bahtiar et al., } \\
2017\end{array}$ & $\mathrm{MKBC}^{3}$ \\
\hline
\end{tabular}


Hal lain yang menarik dari fenomena tingginya nilai $\mathrm{P} / \mathrm{B}$ ditemukan pada beberapa perairan yang sumberdaya kerangnya tereksploitasi. Pada perairan dengan kondisi ini, kecenderungan kerang untuk melakukan strategi $r$ yaitu dengan melakukan reproduksi lebih awal yang terjadi pada umur muda yang berlangsung lebih panjang (6 bulan). Kondisi ini dapat meningkatkan nilai produksi kerang pada ukuran muda yang belum masuk pada daerah penangkapan. Namun kondisi ini tidak diimbangi dengan biomassa kerang produktif dewasa-tua dalam pembentukan jaringan karena telah dieksploitasi (Heilmayer et al., 2004). Hal ini ditunjukkan pada kemampuan pulih kerang pokea di muara Sungai Pohara yang relatif sama dengan di muara Sungai Lasolo yang berkisar 6-9/tahun (Bahtiar, 2012). Oleh karena itu, kemampuan pulih yang terlampau tinggi dapat dijadikan sebagai indikator tingginya tekanan penangkapan di muara Sungai Lasolo.

Kerang pokea dapat tumbuh disebabkan oleh fungsi dari kualitas lingkungan perairan (kualitas air dan ketersediaan makanan). Hasil pengamatan dan pengukuran menunjukkan bahwa kualitas lingkungan perairan di Sungai Lasolo sangat baik dalam menunjang pertumbuhan kerang pokea. Kualitas perairan Sungai Lasolo jauh lebih baik dibanding Sungai Pohara yang juga ditemukan kerang pada jenis yang sama. Hal ini ditandai dengan parameter kualitas air dan ketersediaan makanan di Sungai Lasolo yang lebih tinggi seperti TDS, TOM dan bahan organik substrat). Hasil pengamatan kisaran parameter kualitas perairan di Sungai Pohara pada 3 parameter di atas secara berturut-turut masing-masing yaitu: $(12,54-$ $88,15 \mathrm{mg} / \mathrm{L}),(0,39-2,72 \mathrm{mg} / \mathrm{L})$, dan $(0,68$ 2,63\%) (Bahtiar, 2012). Demikian halnya pemantauan kualitas fisik perairan pada kecepatan arus yang lebih tinggi di Sungai Lasolo. Aliran air yang lebih cepat akan menyuplai makanan dari bagian atas perairan yang berlangsung secara terus menerus ke bagian muara perairan tempat kerang pokea hidup. Oleh karena itu, kerang pokea di sungai ini mempunyai kesempatan dalam memaksimalkan pengambilan makanan melalui mekanisme menyaring makanan dengan menggunakan insang (filter feeder) dan menyapu makanan di lantai dasar perairan dengan menggunakan pedal (deposit feeder). Kondisi ini memberikan kesempatan yang baik bagi kerang di sungai ini untuk mencapai pertumbuhan yang memadai.

\section{KESIMPULAN}

Kepadatan dan produksi kerang pokea di muara Sungai Lasolo tergolong tinggi yang terjadi pada kelompok kerang muda yang jauh melampui pembentukan biomassa yang merupakan fenomena dari potensi reproduksi besar dan berkurangnya ukuran kerang dewasa-tua karena tekanan penangkapan tinggi. Hal ini berimplikasi pada laju pemulihan kerang pokea menjadi sangat cepat.

\section{UCAPAN TERIMA KASIH}

Terima kasih tak terhingga kepada Kemristekdikti yang telah membiayai satu seri/bagian dari penelitian kerang pokea di Sungai Lasolo. Ucapan terima kasih pula, saya haturkan kepada mahasiswa dan kru perahu yang telah membantu terselenggaranya kegiatan ini sehingga hasil penelitian ini dapat dipublikasikan.

\section{DAFTAR PUSTAKA}

Abrahao, J.R., R.S. Cardoso, L.Q. Yokoyama, and C.Z. Amaral. 2010. Population biology and secondary production of the stout razor clam Tagelus plebeius (bivalvia, solecurtidae) on a sand flat in Southeastern Brazil. Zoologia, 27:5464.

Aldridge, D.C. 1999. The morphology, growth and reproduction of unionidae 
(bivalvia) in a Fenland Waterway. $J$. Moll.Stud., 65:47-60.

Arapov, J., D. Ezgeta-Bali, M. Peharda, and Z.N. Gladan. 2010. Bivalve feedinghow and what they eat? Ribarstvo, 68(3):105-116.

Bahtiar dan Hamzah, M. 2007. Konservasi Populasi Pokea (Batissa violacea celebensis Martens 1897) di Sungai Pohara Sulawesi Tenggara. DP2M. Dirjen Pendidikan Tinggi. Jakarta. $100 \mathrm{hlm}$.

Bahtiar, F. Yulianda, dan I. Setyobudiandi. 2008. Kajian aspek pertumbuhan populasi pokea (Batissa violacea var. celebensis, von Martens 1897) di Sungai Pohara Kendari Sulawesi Tenggara. J. Ilmu-Ilmu Perairan dan Perikanan Indonesia, 15(1):1-5.

Bahtiar. 2012. Studi bioekologi dan dinamika populasi pokea pokea (Batissa violacea var. celebensis, von Martens 1897) yang tereksploitasi sebagai dasar pengelolaan di Sungai Pohara Sulawesi Tenggara. Disertasi. Institut Pertanian Bogor. Bogor. 140 hlm.

Bahtiar, E. Riani, I. Setyobudiandi, dan I. Muchsin. 2012a. Kepadatan dan distribusi pokea Batissa violacea var. celebensis, von Martens 1897) pada substrat berbeda di Sungai Pohara Kendari Sulawesi Tenggara. Aqua Hayati, 8(2):115-123.

Bahtiar, E. Riani, I. Setyobudiandi, dan I. Muchsin. 2012b. Pengaruh aktivitas penambangan pasir terhadap kepadatan dan distribusi pokea (Batissa violacea var celebensis, von Martens 1897) di Sungai Pohara Sulawesi Tenggara. Agriplus, 22:5864.

Bahtiar, M. Hamzah, dan H. Hari. 2015. Studi struktur dan pertumbuhan populasi kerang pokea (Batissa violacea var.celebensis, von Martens 1897) di Sungai Pohara Sulawesi Tenggara. J. Biologi Tropis, 15(2):110-120.
Bahtiar, L. Anadi, W. Nurgayah, Emiyarti dan Hari, H. 2016. Pertumbuhan, Kematian, dan Tingkat Eksploitasi Kerang Pokea (Batissa violacea var. celebensis, von Martens 1897) Pada Segmen Muara Sungai Lasolo Sulawesi Tenggara. Marine Fisheries, 7(2):137-147.

Bahtiar. 2016. Biologi reproduksi kerang pokea Batissa violacea var. celebensis, von Martens 1897 di Muara Lasolo, Sulawesi Tenggara. J. Ilmu dan Teknologi Kelautan Tropis, 9(1): 9-18. http://dx.doi.org/10.29244/ jitkt.v9i1.17913.

Beasley, C.R., E. Tury, W.G. Vale, and C.H. Tagliaro. 2000. Reproductive cycle, management and conservation of Paxyodon syrmatophorus (bivalvia: hyriidae) from the Tocantins River, Brazil. J. Moll. Stud., 66:393-402.

Cardoso, R.S. and V.G. Veloso, 2003. Population dynamics and secondary production of the wedge clam Donax hanleyanus (Donacidae) on a highenergy, Subtropical Beach of Brazil. Marine Biology, 142:153-162.

Clemente, S. and B. Ingole. 2011. Recruitment of mud clam Polymesoda erosa (Solander, 1876) in a mangrove habitat of Chorao Island, Goa. Brazilian J. of Oceanography, 59:153-162.

Compton, T.J., R. Kentie, A.W. Storey, I. Veltheim, G.B. Pearson, and T. Piersma. 2008. Carbon isotope signatures reveal that diet is related to the relative sizes of the gills and palps in bivalves. $J$. of Experimental Marine Biology and Ecology, 361(2):104-110.

Darr, A., M. Gogina, and M.L. Zettler. 2014. Detecting hot-spots of bivalve biomass in the South-Western Baltic Sea. J. of Marine Systems, 134:6980.

Davis, S.E., D.L. Childers, J.W.Jr. Day, D.T. Rudnickd, and F.H. Sklard. 2001. 
Nutrient dynamics in vegetated and unvegetated areas of a Southern Everglades Mangrove Creek. Estuarine, Coastal and Shelf Science, 52:753-768.

Djajasasmita, M. 1977. An anotated list of the spesies of the genus Corbicula from Indonesia (Mollusca : Corbiculidae). Bulletin Zoologisch Museum. Universiteit Van Amsterdam. Amsterdam. $9 \mathrm{hlm}$.

Dudgeon, D. and B. Morton. 1989. The population dynamics and sexual strategy of Anodonta woodiana (bivalvia: unionidae) in Plover Cove Reservoir, Hongkong. J. Zool., Lond., 201:161-183.

Duobinis, G.E.M. and C.T. Hackney. 1982. Seasonal and spatial distribution of the Carolina marsh clam Polymesoda caroliniana (Bosc, 1801) in a sizes of the gills and palps in bivalves. $J$. of Experimental Marine Biology and Ecology, 361:104-110.

Etim, L. 1996. Determination of reproduction cycle in a population of Egeria radiate (Lam, 1804) (bivalvia: donacidae) using condition index and histological examination of gonads. Annls Limnol., 32(2):105-113.

Ercan, E., O. Gaygusu, A.S. Tarkan, M. Reichard, and C. Smith. 2013. The ecology of freshwater bivalves in the Lake Sapanca Basin, Turkey. Turk. J. Zool., 37:730-738.

Flores-Garza, R., V. Lopez-Rojas, P. FloresRodriguez, and C.T. Ramirez. 2014. Diversity, distribution and composition of the bivalvia class on the rocky intertidal zone of marine priority region 32, Mexico. Open $J$. of Ecology, 4:961-973.

Guissan, A., A. Lehmann, S. Ferrier, M. Austin, J.M.C. Overton, R. Aspinall, and T. Hastie. 2006. Making better biogeographical predictions of species distribution. J. of Applied Ecology, 43:386-392.
Heilmayer, O., T. Brey, D. Storch, A. Mackensen, and W.E. Arntz. 2004. Population dynamics and metabolism of Argopecten opercularis (L.) from the Western English Channel (Roscoff, France). J. of Sea Research, 52:33-44.

Hermann, M., D. Carstensen, S. Fischer, J. Laudien, P.E. Penchaszadeh and W.E. Artnz. 2009. Population structure, Growth, and production of the wedge clam Donax hanleyanus (bivalvia: Donaidae) from Argentinean beaches. J. of Shellfish Research, 28(3):511526.

Hermann, M., J.E.F. Alfaya, M.L. Lepore, E.P. Penchaszadeh, and W.E. Arntz. 2010. Population structure, growth and production of the yellow clam (bivalvia: mesodesmatidae) from high energy, temperate beach in Northern Argentina. Springer Verlag, 65:285297.

Çolakoğlu,S. 2014. Population structure, growth and production of the wedge clam Donax trunculus (Bivalvia, Donacidae) in the West Marmara Sea, Turkey. Turkish J. of Fisheries and Aquatic Sciences, 14:221-230.

Irma, D. and K. Sofyatuddin. 2012. Diversity of gastropods and bivalves in mangrove ecosystem rehabilitation areas in Aceh Besar Banda Aceh Districts, Indonesia. Bioflux, 5:55-59.

Jutting, W.S.S.V.B. 1953. Systematic studies on the non-marine mollusca of the Indo-Australian Archipelago. Treubia, 22(1):19-73.

Kabir, M., M. Abolfathi, A. Hajimoradloo, S. Zahedi, K. Kathiresan, and S. Goli. 2014. Effect of mangroves on distribution, diversity and abundance of molluscs in mangrove ecosystem: a review. Bioflux, 4:286-300.

Kevrekidis, T., K. Kasapis, and V. Kalpia. 2009. Life cycle, population dynamics, growth and production of Abra segmentum (mollusca, bivalvia) 
at low salinitiesin a Mediterranean Lagoon. Helgol Mar Res., 63:277285.

Laudien, J., T. Brey, and W.E. Arntz. 2003. Population structure, growth and production of the surf clam Donax serra (bivalvia, donacidae) on two Namibian sandy beaches. Estuarine, Coastal and Shelf Science, 58:105115

Lomolino, M.V., D.F. Sax, B.R. Riddle, and J.H. Brown. 2006. The island rule a research agenda for studying ecogeographical patterns. $J$. of Biogeography, 33:1503-1510.

Lomovasky, B.J., T. Brey, E. Morriconi, and J. Calvo. 2002. Growth and production of the venerid bivalve Eurhomalea exalbida in the Beagle Channel, Tierra del Fuego. J. of Sea Research, 48:209-216.

Lomovasky, B.J., A.M. Casariego, T. Brey, and O. Iribarne. 2006. The effect of the SW Atlantic burrowing crab Chasmagnathus granulates on the intertidal razor clam Tagelus plebeius. J. of Experimental Marine Biology and Ecology, 337:19-29.

Mayor, A.D., R.C. Ancog, R.D. Guerrero, and M.V.C.Camacho. 2016. Enviromental factors influencing population density of freshwater clam Batissa violacea (bivalvia) (Lamarck, 1818) in Cagayan River, Northern Philippines. International J. of Aquatic Science, 7(2):63-72.

Musin, G.E., F.R. Molina, F. Giri, and V. Williner. 2015. Structure and density population of the invasive mollusc Limnoperna fortuneiassociated with Eichhornia Crassipes in Lakes of the Middle Paraná Floodplain. J. Limnol., 74(3):537-548.

Nasution, S. and Zulkifli. 2014. Species richness and abundance of bivalvia and gastropoda (molluscs) in mangrove forest of Dumai City, Riau Province. International J. of
Innovation and Applied Studies, 4(9):1981-1986.

Nichols, S. J., H. Silverman, T.H. Dietz, J.W. Lynn, and D.L. Garling. 2005. Pathways of food uptake in native (unionidae) and introduced (corbiculidae and dreissenidae) freshwater bivalves. $J$. of Great Lakes Research, 31:87-96.

Ocaña, F.A. 2015. Growth and production of Donax striatus (bivalvia: donacidae) from Las Balsas Beach, Gibara, Cuba. Revista de Biologia Tropical, 63:639-646.

Paschoal, L.R.P., D.P. Andrade, and G. Darrigran. 2013. Size comparison of quadrats in sample of non-native bivalve Corbicula fluminea (Muller, 1774) (bivalvia: corbiculidae). PanAmerican J. of Aquatic Sciences, 8(4):369-374.

Printrakoon, C., F.E. Wells, and Y. Chitramvong. 2008. Distribution of molluscs in mangroves at six sites in the upper gulf of Thailand. The Raffles Bulletin of Zoology, 18:247257.

Ricciardi, A. and E. Bourget, 1998. Weightto-weight conversion factors for marine benthic macroinvertebrates. Marine Ecology Progress Series, 163:245-251.

Rua, A.R., M.A. Prado, Z. Romero, and M. Bruzon. 2003. The Gametogenic cycle of Scrobicularia plana (da Costa, 1778) (mollusc: bivalve) in Guadalquivir Estuary (Cadiz, SW Sapin). Aquaculture, 217:157-166.

Rueda, M. and H.J. Urban. 1998. Population dynamics and fishery of the freshwater clam Polymesoda solida (corbiculidae) in Cienaga Poza Verde, Salamanca Island, Colombian Caribbean. Fisheries Research, 39:75-86.

Sousa, R., J.A. Antonio, J.A. Nogueira, M.B. Gaspar, C. Antunes, and L. Guilhermino. 2008. Growth and 
etremely high production of the nonindigenous invasive species Corbicula fluminea (Muller, 1774): possible implications for ecosystem functioning. J. Estuarine, Coastal and Shelf Science, 80:289-295.

Suwondo, E. Febrita, dan N. Siregar. 2012. Kepadatan dan distribusi bivalvia pada mangrove di Pantai Cermin Kabupaten Serdang Bedagai Provinsi Sumatera Utara. J. Biogenesis, 9(1): 45-50.

Thangavelu, A., B. David, B. Barker, J. Geneste, J. Delannoy, L. Lamb, and R. Skelly. 2011. Morphometric analyses of Batissa violacea shells from Emo (OAC), Gulf Province, Papua New Guinea. Archaeol. Oceania, 46:67-75.

Turra, A., M. Petracco, A.C.Z. Amaral, and M.R. Denadai. 2014. Population biology and secondary production of the harvested clam Tivela mactroides (Born, 1778) (bivalvia, veneridae) in Southeastern Brazil. Marine Ecology, 36:221-234.

Vaughn, C.C., S. J. Nichols, and D.E. Spooner. 2008. Community and foodweb ecology of freshwater mussels. J. N. Am. Benthol. Soc., 27(2):409-423.

Yanovych, L.M. 2015. Reproductive features of indigenous and the invasive Chinese freshwater mussels (mollusca, bivalve, anodontidae) in Ukraine. Vestnik zoologii, 49(5):433438.

Yeni. 2012. Aktivitas antioksidan dan pengaruh pengolahan terhadap kandungan gizi kerang pokea (Batissa violacea celebensis, Martens 1897) di Sungai Pohara Sulawesi Tenggara. Tesis. Institut Pertanian Bogor. Bogor. $91 \mathrm{hlm}$.

Zabbey, N., A.I. Hart, and W.J. Wolf. 2010. Population structure, biomass and production of the West African Lucinid Keletistes rhizoecus (bivalvia, mollusca) in sivibilagbara swamp at Bodo Creek, Niger Delta, Nigeria. Hydrobiologia, 654:193203.

$\begin{array}{ll}\text { Diterima } & : 21 \text { Juli } 2017 \\ \text { Direview } & : \text { :02 Agustus } 2017 \\ \text { Disetujui } & : 23 \text { Juli } 2018\end{array}$


